\title{
Local Capacity Building in Humanitarian Crises: An Effective Dealing Strategy for Bangladesh
}

\author{
Golam M. Mathbor \\ School of Social Work, Monmouth University, USA
}

Copyright $\bigcirc 2016$ by authors, all rights reserved. Authors agree that this article remains permanently open access under the terms of the Creative Commons Attribution License 4.0 International License

\begin{abstract}
Bangladesh is a country which is geographically prone to disaster. It is exposed to some common disasters (cyclone, flood, tornado, and drought are among them) in every year that have resulted in heavy damages in economic, social, and human life. The main causes behind these damages are high vulnerability of people (unaware), housing (dilapidated), location (coastal area), and infrastructure (lack of dam, embankment, and shelter house). Hazards are increasing day by day due to climate change. Using burning fossil fuel and other unsafe energy at a record amount, we are contributing to climate change. No short term initiative can be taken as a tool of disaster management. There should be a comprehensive approach before, during and in the post disaster period comprising disaster preparedness, mitigation, response, and recovery.
\end{abstract}

Keywords Bangladesh, Vulnerability, Hazards, Climate Change, Disaster

\section{Introduction}

From inception as an independent nation, Bangladesh has been exposed to various disasters that have caused heavy damages. Cyclones in 1970 and 1991, and flood in 1998 were devastating disasters that claimed millions of lives. Recently Cyclone 'Sidr' showed our extreme vulnerability to hazard. This paper intends to unearth the actual causes of disaster, the effort of government to deal with the disaster, and what is being done by the government of Bangladesh. For that, the concept of disaster and disaster management gets special attention in Bangladesh. More attention goes to cyclone (most frequent) especially Cyclone Sidr, which resulted in high social and economic damages.

\section{Understanding Disaster}

\section{A. Definition of Disaster}

Disaster should not be confused with catastrophe or any other accident. Disaster causes such damage that requires large-scale response outside the affected community. It is defined by World Health Organization (WHO) as "any occurrence that causes damage, ecological disruption, loss of human life, deterioration of health and health services, on a scale sufficient to warrant an extraordinary response from outside the affected community or area." [1]

\section{B. Classification of Disaster}

Generally, disaster is classified into two types - natural and human-made. Considering the nature, causes, and sources of disaster, it can then be classified into two distinct classifications, though they are overlapping:

1. Natural Disaster: It refers to disaster caused by nature, such as earthquakes, cyclone, volcano, erosion, hurricanes, etc.

2. Human-made Disaster: It includes the disasters caused by human beings, either deliberately or accidental, such as fire, terrorism, riot, pollution, accidents, war, etc.

\section{Causes of Disaster}

To understand the causes of disaster we will analyze the disaster in the following way:

$$
\text { Disaster }=\frac{\text { Hazard } X \text { Vulnerability }}{\text { Capacity }}
$$

Be sure to differentiate hazard from disaster. In Bangladesh, hazard is popularly termed as disaster. Say, we call flood, earthquake, etc. hazards disaster; we are wrong. A hazard can be called disaster if it affects certain portions of society to such an extent that people need an extraordinary response from outside the community. Absence of capacity can be termed as vulnerability and similarly capacity lacks vulnerability. These two can be clearly understood from the table presented below. 
Table 1. Capacity and vulnerability analysis matrix ${ }^{[2]}$

\begin{tabular}{|c|l|l|}
\hline & \multicolumn{1}{|c|}{ Vulnerabilities } & \multicolumn{1}{|c|}{ Capacities } \\
\hline \multirow{3}{*}{ Physical factors } & $\begin{array}{l}\text { Geographical calamities (floods, earthquake) } \\
\text { Economic misfortunes (drought) } \\
\text { Poverty (insufficient resources) } \\
\text { Lack of infrastructure } \\
\text { Poor health }\end{array}$ & $\begin{array}{l}\text { Skills to be productive } \\
\text { Access to productive resources (land, forest, sea, capital, etc.) } \\
\text { Technologies (agro-forestry/sustainable land management) } \\
\text { Adequate infrastructure } \\
\text { Good health }\end{array}$ \\
\hline Social organization & $\begin{array}{l}\text { Division according to religion, ethnicity, language, } \\
\text { class or caste } \\
\text { Prejudice Conflict Ineffective community } \\
\text { organization process }\end{array}$ & $\begin{array}{l}\text { Social coping mechanism: family, group, community and/or area } \\
\text { wide organizations } \\
\text { Resilience, unity, solidarity }\end{array}$ \\
\hline \multirow{2}{*}{ Attitudes } & $\begin{array}{l}\text { Superstition } \\
\text { Fatalism (feeling that nobody supports them). } \\
\text { Dependence on external support }\end{array}$ & $\begin{array}{l}\text { Fighting spirit } \\
\text { Religion } \\
\text { Sense of purpose }\end{array}$ \\
\hline
\end{tabular}

Following are examples of appearance of hazards, vulnerabilities of community, and capabilities of communities dealing with major disasters:

1. Appearance of hazards: flood, landslide, earthquake, volcano, etc.

2. Vulnerable community: physical (e.g., disabled, illness, aged), social (e.g., unfavorable location, helplessness, lack of awareness, unskilled), economic (e.g., houses made of light materials, poverty, economic depression ), cultural (e.g., fatalism)

3. Less capable community: capacity is knowledge, skills, resources, abilities, and strength, present in individuals, households, and the communities, which enable them to prevent, prepare for, stand against, survive and recover from disaster. Capacity are permanent houses, ownership of land, adequate food and income services, family and community support in time of crisis, local knowledge, strong community leadership and organization.

\section{Disaster Grabs Bangladesh}

\section{A. The North Indian Ocean Cyclone Season}

The North Indian Ocean cyclone season is an event in the annual cycle of tropical cyclone formation. The North Indian Ocean cyclones tend to form between April and December, with peaks in May (Nargis) and November (Sidr). The North Indian Ocean denotes to the Indian Ocean in the Northern Hemisphere, east of the Horn of Africa and west of the Malay Peninsula. There are two main seas in the North Indian Ocean - Arab Sea and the Bay of Bengal. The official Regional Specialized Meteorological Centre in this basin is the India Meteorological Department (IMD), while the Joint Typhoon Warning Center releases unofficial advisories. The tropical cyclone scale for this basin is detailed as follows. On average, 4 to 6 storms form in this basin every season. ${ }^{[3]}$

The following cumulative track map shows the vulnerability of South Asia. 


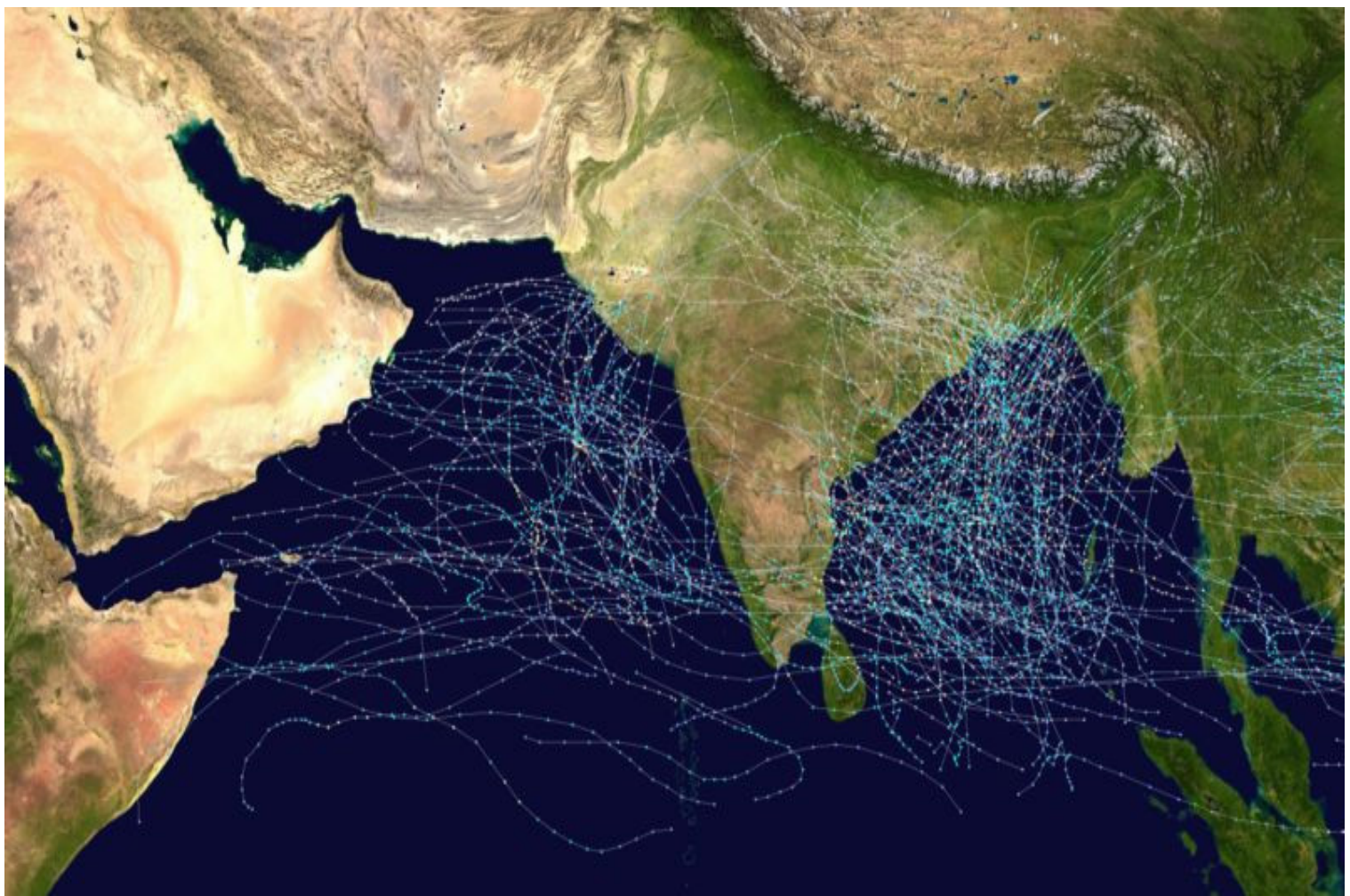

Figure 1. Cumulative track map of all North Indian Ocean Cyclones from 1970 to $2005^{[4]}$

It is a matter of worry that the tropical cyclone scale is increasing day by day. In 2006 the IMD named three North Indian Ocean storms - Mala, Mukda, and Ogni. This list expands into four in 2007 namely Akash, Gonu, Yenyin, and Sidr; and into five in 2008 including Nargis, Abe, Khai-Muk, Nisha, and Bijli. IMD is forecasting seven (more than previous year) Ocean storms in the ongoing year [5] (2009). These are Bijli (unused), Aila (unused), phyan (unused), Ward (unused), Laila (unused), Bandu (unused), and Phet (unused). These increasing events of storms are diagrammed here.

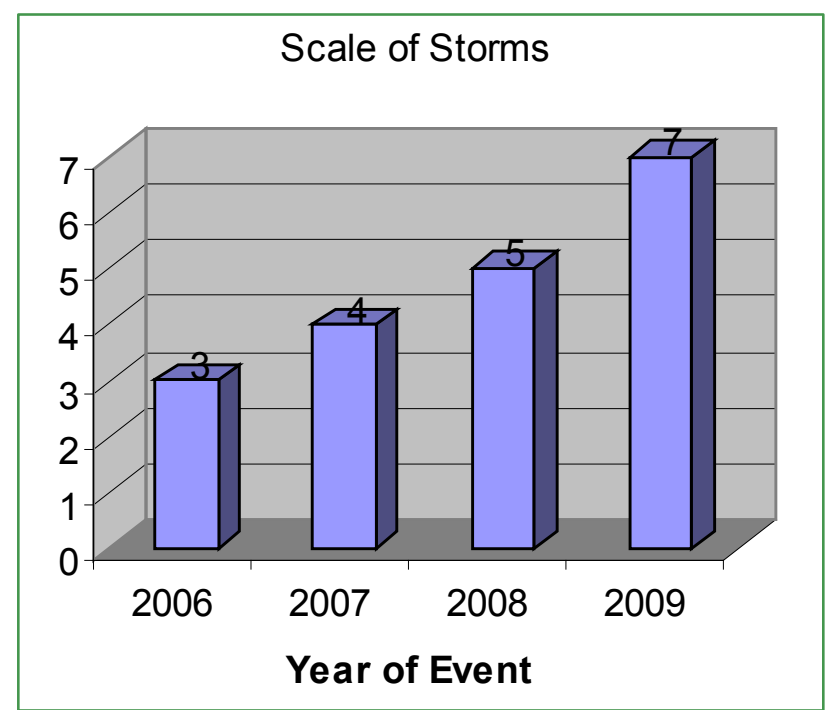

Figure 2. The Increasing Occurrence of Storms

\section{What about Bangladesh?}

Bangladesh is a country of South Asia which is bordered by India on all sides except for a small border with Burma to the far southeast and by the Bay of Bengal to the south. It is under the range of North Indian Ocean. Most parts of Bangladesh are less than 12 meters $(39 \mathrm{ft})$ above the sea level, and it is believed that about $50 \%$ of the land would be flooded if the sea level were to rise by a meter $(3 \mathrm{ft}) .{ }^{[6]}$ As a result it is exposed to high episodes of disaster. The significant disasters that have happened in Bangladesh are given below ${ }^{[7]}$

Table 2. Disaster type and loss of life in Bangladesh during 1970-2007

\begin{tabular}{|c|c|c|}
\hline Year & Types of Disaster & Loss of life \\
\hline 1970 & Cyclone & 300,000 \\
\hline 1973 & Cyclone & 103 \\
\hline 1974 & Flood \& famine & 30,000 \\
\hline 1983 & Cyclone & 383 \\
\hline 1985 & Cyclone & 11,069 \\
\hline 1987 & Flood & 1657 \\
\hline 1988 & Flood & 2379 \\
\hline 1988 & Cyclone & 5,708 \\
\hline 1991 & Cyclone & 138,848 \\
\hline 1996 & Tornado & 545 \\
\hline 1997 & Cyclone & 155 \\
\hline 1998 & Flood & 918 \\
\hline 2000 & Flood & 36 \\
\hline 2004 & Flood & 747 \\
\hline 2007 & Landslides in Chittagong & 127 \\
\hline 2007 & Flood & $516^{[8]}$ \\
\hline 2007 & Cyclone Sidr & $3,363^{[9]}$ \\
\hline
\end{tabular}




\section{Disaster Management}

Disaster Management can be defined as "The body of policy and administrative decisions, and operational activities which pertain to the various stages of disaster at all level". Here, "Policy and administrative decisions, and operational activities" refer to the disaster cycles that include disaster mitigation, disaster preparedness, disaster response, and disaster recovery. These cycles of disaster management are shown below in a cyclic fashion.

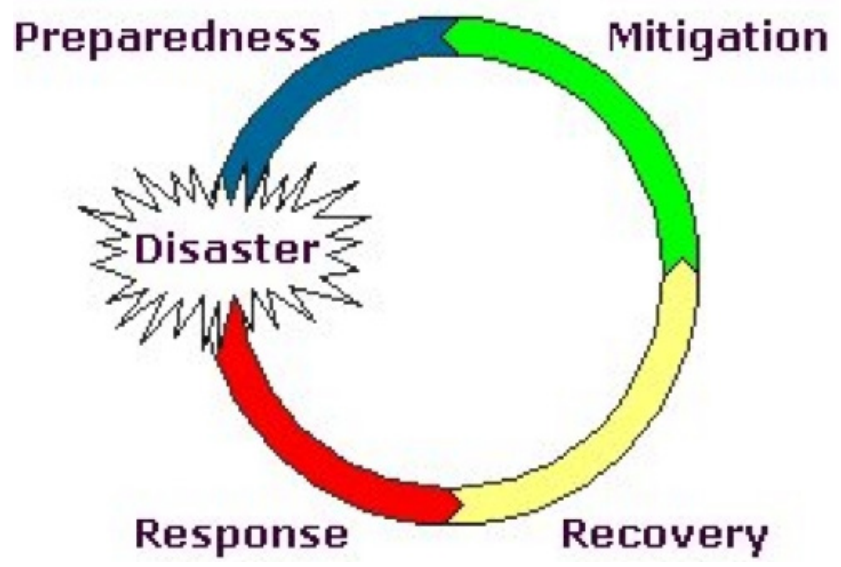

Figure 3. The Disaster Management Cycle. [10]

\section{A. Disaster Mitigation}

Disaster mitigation is a set of programs which are taken to limit the adverse impact of hazards. It focuses on long term measures for reducing or eliminating the risk. Disaster mitigation activities include:

1. Engineering- dam, embankment, etc.;

2. Spatial planning- safe zone for resettlement;

3. Management \& institutionalization- education, training, awareness building, development of professional experts;

4. Structural (shelter center, dam, embankment, etc.) \& non-structural (legislation, policy, planning);

5. Economic structure- stronger building, safe site, longer financial reserve, etc.

\section{B. Disaster Preparedness}

In this phase, disaster manager develops plans of action for the time when disaster strikes. It refers to the effective readiness measures to expedite emergency action, rehabilitation and recovery. Disaster preparedness includes emergency warning, emergency shelter, emergency evacuation disaster plans, and maintenance of resources and training of personnel.

\section{Disaster Response}

The response phase includes the mobilization of the necessary emergency services and first responders in the disaster affected area. Here, necessary emergency services include search and rescue, evacuation, demand analysis, resource analysis, emergency relief (food, water, sanitation, first aid, etc.) and logistic supply (tent). By first responders, we mean fire fighters, police, social workers, volunteers, Community Based Organizations (CBOs), and Non-Governmental Organizations (NGOs).

\section{Disaster Recovery}

The aim of disaster recovery is to restore the affected area to its previous state. It includes

1. Rehabilitation: cleaning up the debris, rebuilding destroyed houses and property, re-employment, etc.

2. Reconstruction: rebuilding or repairing the essential infrastructure e.g., roads, hospital, schools, etc.

The following is a short list of disaster cycles:

- Mitigation- minimizing the effects of a disaster

- Preparedness- planning how to respond to a disaster

- Response- minimizing the hazards created by an emergency

- Recovery-returning the community or environment to normal

\section{Disaster Management and Bangladesh}

The people of Bangladesh are repeatedly confronted by natural and human-made catastrophes such as flooding, surface and groundwater pollution, droughts, cyclones, riverbank erosion, air pollution, wetland loss, tornadoes, earthquakes, and coastal erosion. Disaster management of the Government of Bangladesh (GoB) goes forward with the help of the Ministry of Food and Disaster Management.

\section{A. The Ministry of Food and Disaster Management}

In line with the paradigm shift from relief and response to comprehensive disaster management, the home of the Ministry of Relief and Rehabilitation was changed to the Ministry of Disaster Management and Relief in 2003, and it was again renamed as the Ministry of Food and Disaster Management (MoFDM). A series of inter-related institutions were developed to ensure that planning and coordination of disaster episodes were performed in accordance with the Standing Order on Disasters (SoD). There are three agencies within the Ministry of Food and Disaster Management. These are

- Disaster Management Bureau (DMB)

- Directorate of Relief and Rehabilitation (DRR)

- Directorate of Food (DoF)

\section{B. Disaster Management Strategy of GOB}

After the floods of late 1980s and the devastating cyclone of 1991, the concept of acting only after the occurrence of disaster has been replaced by the concept of total disaster management involving prevention/mitigation, preparedness, response, and recovery. There are two basic strategies emphasized by the GoB. These are:

Capacity building: The $\mathrm{GoB}$ has, therefore, total 
commitment towards reduction of human, economic and environmental costs of disasters by enhancing overall disaster management capacity.

Coordination: Efforts have been continuing for effective coordination and best utilization of resources along-with ensuring community involvement so that the community is aware of what they can do to protect lives and properties against disasters.

\section{Disaster Management Cycle}

The plan and conduct of disaster management by GoB involves preparedness, response, recovery and mitigation as key techniques for building up self-reliance of the community people.

Disaster Mitigation: Government gives equal importance to both structural as well as non-structural mitigation measures.

Structural Mitigation:

- Cyclone shelters: 2,023

- Flood shelters: 200

- Coastal Embankment: $3,931 \mathrm{~km}$.

- Drainage channels: $4774 \mathrm{~km}$.

Non-Structural Mitigation: For non-structural mitigation GoB has given emphasis on

- Legislation \& Policy: Relating to preparedness and emergency measures and rehabilitation program to deal with disaster.

- Training and Public Awareness: As part of training and public awareness, nearly 50,000 people related to disaster have been trained through 500 courses/workshops/seminars.

As part of public awareness activities, booklets containing information about cyclone, flood etc. and calendar, posters depicting disaster points have been regularly printed and distributed up to the grass-root levels.

To raise awareness among the students on various hazards / disaster management, a chapter on disaster management has been included in the educational curricula from grades six to twelve. GoB has decided to make compulsory a session of at least two hours on disaster management in the training curricula of all types of Training Institutes to train both formal and informal (non-salaried) officials.

\section{Disaster Management Mechanism}

At Nation level: The initial operational direction and co-ordination for any disaster situation comes from the highest level of institutional arrangement (i.e., National Disaster Management Committee) through second highest authority Inter Ministerial Disaster Management Coordinating Committee is working for overall disaster management in the country.
At Local level: Committees from National to Grassroots levels i.e. District Disaster Management Committee (DDMC), Upazila Disaster Management Committee (UzDMC) and Union Disaster Management Committee (UDMC) are working under the framework of disaster management guidebook i.e. Standing Orders on Disaster work on Disaster Management.

\section{E. The Comprehensive Disaster Management Program}

The Comprehensive Disaster Management Program (CDMP) was approved by the Bangladesh Government in 2003 as a key strategy to advance entire government and agency risk reduction efforts in the country.

CDMP is a strategic institutional and programming approach that is designed to optimize the reduction of long-term risk, and to strengthen the operational capacities for responding to emergencies and disaster situations, including actions to improve recovery from these events.

Key benefits associated with this approach are:

- The resources and expertise of government, NGOs, private sector and the community are deployed according to national priorities and community risk reduction programming needs.

- It provides a big picture of what needs to be done and as such, a mechanism for identifying gaps, monitoring, and observing achievement.

- It provides the basis upon which formal collaborating partnerships are developed and nurtured.

\section{Example of Effective Disaster Coordination Systems}

The following are some of the effective disaster management approaches that Bangladesh can take into consideration improving disaster mitigation, preparedness, response, and recovery strategies.

\section{A. The Queensland Disaster Management System}

Queensland, a state of Australia, is bordered by the Coral Sea and Pacific Ocean and usually exposed to disaster. To address disaster effectively, it maintains relations with international bodies in addition to local organizations. The disaster management system in Queensland is diagrammed below.

Following figure depicts the Queensland Disaster Management System including the link to the Commonwealth for National-level support when required. 


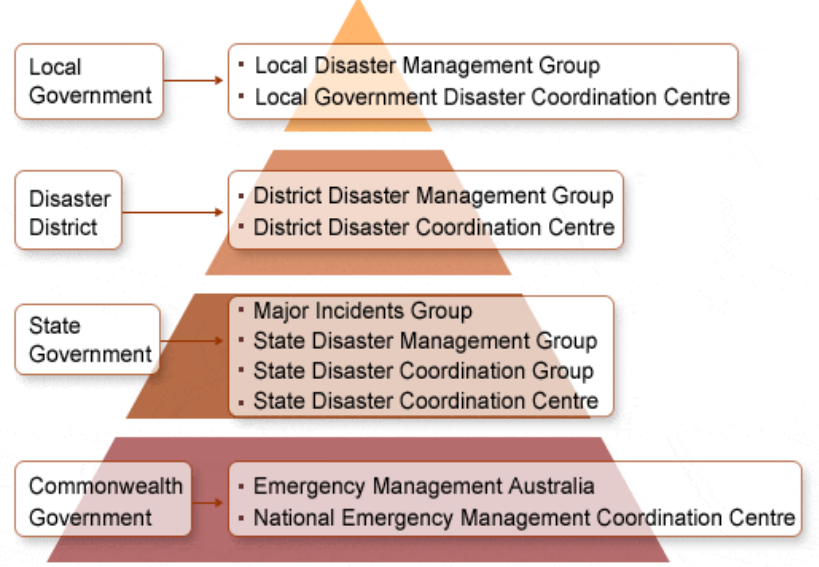

Figure 4. The Queensland Disaster Management System ${ }^{[1]}$

\section{B. Netherlands: An Example of a Long Term Approach:}

The Delta project, a vast construction effort (consists of dams, sluices, locks, dikes, and storm surge barriers); designed to end the threat from the sea once and for all was launched in 1958 and largely completed in 2002. The Dutch government often cites the Delta Works project as the world's largest flood protection project. With over 10,250 miles of dikes (1,500 miles designated as primary dikes, and 8,750 miles as secondary dikes) and 300 structures, the project is one of the most extensive engineering projects in the world. ${ }^{[12]}$

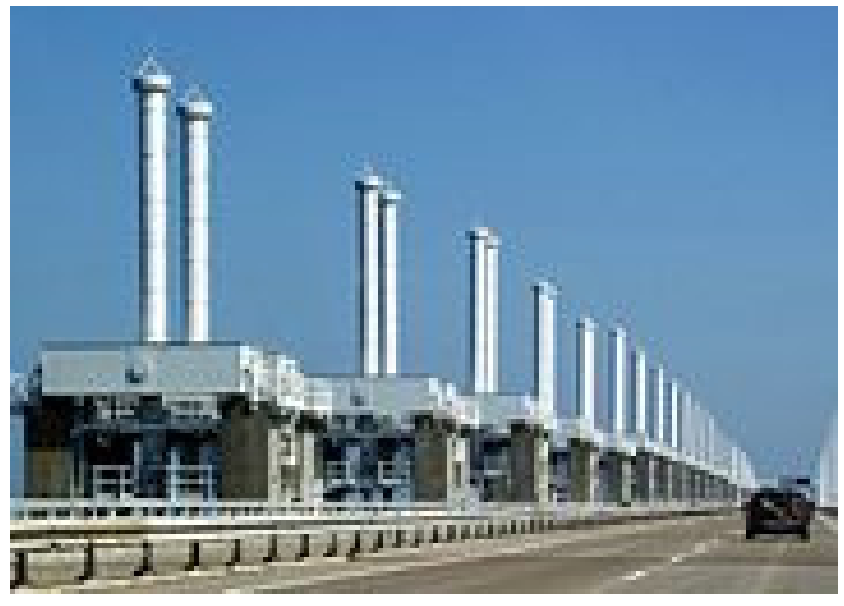

Figure 5. Oosterscheldekering, the largest of 13 Delta Works' dams.

\section{BDRCS Cyclone Preparedness Program's Response to Cyclone Sidr}

Cyclone Sidr, the fourth named storm of the 2007 North Indian Ocean cyclone season, caused heavy damages (human life, social, and economic) in Bangladesh and affected 30 districts and claimed 3,363 lives. It was formed in the central Bay of Bengal on November 9, 2007, and quickly strengthened to reach peak 1-minute sustained winds of $260 \mathrm{~km} / \mathrm{h}(160 \mathrm{mp} / \mathrm{h})$ on November 16, 2007. It was a Category-5 equivalent tropical cyclone on the
Saffir-Simpson Scale. ${ }^{[13]}$

Cyclone Sidr slammed the highly vulnerable low lying densely populated coastal areas of Bangladesh with heavy rain, winds, and a storm surge. It resulted in large scale damage in the south and south-west regions of Bangladesh. Total scenario of this devastation cyclone is presented in Table 3.

Table 3. Sectors damaged during Cyclone 'Sidr' in November 16, 2007

\begin{tabular}{|c|c|}
\hline Sectors of Damage & Quantity \\
\hline No. of Affected Districts & 30 (Barguna- 1277) \\
\hline No. of Most Affected Districts & 12 \\
\hline No. of Affected Upazila & 200 \\
\hline No. of Affected Union/Pourashava & 1,950 \\
\hline No. of Affected Families & $2,064,026$ \\
\hline No. Affected People & $8,923,259$ \\
\hline Fully damaged crops & 742,826 acres \\
\hline Partially damaged crops & $1,730,116$ acres \\
\hline No. of fully damaged households & 563,877 \\
\hline No. of partially damaged households & 955,065 \\
\hline No. deaths, people & 3,363 \\
\hline No. of Injured People & 55,282 \\
\hline No. missing people & 871 \\
\hline No. of Livestock deaths & $1,778,507$ \\
\hline $\begin{array}{l}\text { No. of fully damaged educational } \\
\text { institutions }\end{array}$ & 4,231 \\
\hline $\begin{array}{l}\text { No. of partially damaged educational } \\
\text { institutions }\end{array}$ & 12,723 \\
\hline Fully damaged roads & $1,714 \mathrm{~km}$ \\
\hline Partially damaged roads & $6,361 \mathrm{~km}$ \\
\hline No. of damaged bridges/culverts, & 1,687 \\
\hline Embankment & $1,875 \mathrm{~km}$ \\
\hline No. of damaged trees & $4,065,316$ \\
\hline
\end{tabular}

Source: Ministry of Food and Disaster Management ${ }^{[9]}$

Cyclone Sidr is considered the strongest cyclone to hit the country since a cyclone killed over 138,000 Bangladeshis in 1991. Deaths from Sidr numbered in the hundreds, and damages to homes, crops and livelihoods were extensive. The volunteers of BDRCS 'Cyclone Preparedness Program (CPP) assisted evacuating 600,000 people and helped them to refute to shelter houses. Bangladesh was in the path of the storm. Many were housed in 1,800 multipurpose disaster shelters built along the coast. Relief organizations distributed seven-day emergency disaster kits of food, blankets and clothing for evacuated families. ${ }^{[14]}$

There was significant response from both national and international level to address this devastating cyclone. Government of Bangladesh (GoB) deployed 18 Bangladesh Air Force helicopters and five Bangladesh Navy ships immediately to supply food, medicine, and relief for the hardest-hit areas. Saudi Arabia also donated US\$100 
million to the relief effort as the country's largest relief sum ever. $^{[15]}$

The European Commission also released $€ 1.5$ million (US\$2.4 million) in emergency relief to Bangladesh. The United States, through the U.S. Agency for International Development, pledged more than US\$14.4 million in emergency assistance, including more than US\$10 million in food assistance from the U.S. Food for Peace program ${ }^{[16]}$. The United States Navy also released over 3,500 Marines aboard USS Kearsarge and USS Essex (located in the Gulf of Oman) and USS Tarawa (located in Hawaii) to aid in the recovery efforts. ${ }^{[17]}$

\section{Recommendations for Effective Disaster Management}

\section{A. Before the Disaster}

Before any disaster, government should undertake disaster mitigation and preparedness programs. The following suggestions can be considered at the mitigation and preparedness stage of disaster management.

\section{Disaster Mitigation}

- Identifying frequent disasters e.g., flood, cyclone, tornado, earthquakes and fixing the priority e.g., Cyclone.

- Constructing permanent embankments and developing a system of caring. In this case, an embankment can be built on a priority basis.

- Constructing sufficient dams and developing a system of caring can also be left to an NGO or agency on profit basis for fisheries.

- In the case of social forestry, coastal areas and riverbanks should get priority.

- Constructing more houses to be used as shelter during the disaster such as schools, madrassas, mosques, community houses having sufficient sanitary latrine, provision of safe water, etc.

- Maintaining planned urbanization. Before another disaster occurs, this is a good time to evaluate old Dhaka (capital of Bangladesh) which is very much vulnerable to earthquake.

- Maintaining a sound sewerage and drainage system. Firstly, managing sufficient number of sewers and drains, and second, a cleaning program in June/July (the peak months for urban flooding).

- Effective river management- dredging the rivers, avoiding floods by water management of international rivers.

Disaster Preparedness

- Creating more awareness programs such as use of posters, billboards, advertising in Mass Medias, and providing information about what to do at the time of disaster.
Existing forecasting system needs to be upgraded and updated on a regular basis.

- Preservation of foods at regional stocks to serve the affected people effectively.

- An on-going training program for CBOs, NGOs, and government officials about search and rescue, evacuation, first aid, and other logistics.

\section{B. During the Disaster}

In this phase, government should mobilize the first responders (fire fighter, police, army, doctors, engineer, social workers, and volunteers of CBOs, NGOs) to expedite the following operations:

- Search and rescue operation;

- Evacuation to shelter houses;

- Needs analysis- food, safe water, first aid, medical services esp., mobile hospital, etc.

- All efforts of relief should be administered under the unique umbrella of GoB.

\section{After the Disaster}

In this phase, government's attention should go to rehabilitation and reconstruction that includes:

- Provide assistance in rebuilding the affected houses by giving aid and/or interest free loan;

- Supplying fertilizer and hybrid seeds as well as agro-loans to affected farmers;

- Re-employing the people who have lost their jobs. For this purpose government should provide (at free of cost or as interest free loan) the means of production-fishing net, fishing boat, cow, goat, etc so that they can be re-employed;

- Provision of rationing on temporary basis;

- Selling rice and essential goods in open market during this period;

- Learning the lessons from present disasters.

\section{Conclusions}

To sum up the paper it can, frankly, be said that Bangladesh is situated in a peak zone (Northern Hemisphere of the Indian Ocean) for hazards. The range of hazards is increasing day by day. These hazards appear as a great disaster of Bangladesh due to its vulnerability and less capacity. There must be a strong body to create awareness and teach people in dealing with disaster, to build sufficient construction to avoid or at least lessen the adverse impact of hazards and to develop the necessary mechanism to care for disaster affected people and areas. There need to have a well-coordinated policy and planning in order to strengthen the disaster management cycles at all levels such as mitigation, preparedness, response, and recovery. There may be an interregional or global concurrence on protecting climate change. 


\section{REFERENCES}

[1] www.nhtsa.dot.gov/PEOPLE/injury/ems/emstraumasystem03 /glossary.htm. Retrieved on 2009-01-05

[2] Kieft Johan and Nur Aspian (2000), Community-based disaster management: a response to increased risks to disaster with emphasis on forest fires. Retrieved on 2007-11-16

[3] IMD Cyclone Warning Services: Tropical Cyclones

[4] http://en.wikipedia.org/wiki/List_of_North_Indian_Ocean_cy clone_seasons. Retrieved on 2009-01-05

[5] http://en.wikipedia.org/wiki/2009_North_Indian_Ocean_cycl one season. Retrieved on 2009-01-05

[6] "Hundreds dead after cyclone rips through Bangladesh", Turkish Press (16 November 2007). Retrieved on 2007-11-16

[7] Disaster Management Guidebook (2002).Disaster Management Project, CARE, Bangladesh. (Bangla version)

[8] http://www.dmb.gov.bd/pastdisaster.html. Retrieved on 2009-01-06
[9] http://www.dmb.gov.bd/last\%20disaster.html. Retrieved on 2008-01-27.

[10] http://www.dmc.gov.lk/Phases_\%20of_\%20the_Disaster.htm 1. Retrieved on 2009-01-06

[11] http://www.disaster.qld.gov.au/about/ Retrieved on 2009-0105

[12] http://en.wikipedia.org/wiki/Delta_Works

[13] Ball, Steph (15 November 2007). "Severe Cyclone Sidr hurtles towards Bangladesh by Steph Ball". BBC Weather. BBC World. Retrieved on 2007-11-15.

[14] "Bangladesh: Improved Flood Response" (pdf) (in English). Humanitarian Information Unit, US Department of State (2007-11-16). Retrieved on 2008-01-27.

[15] Hundreds dead after cyclone rips through Bangladesh", Turkish Press (16 November 2007). Retrieved on 2007-11-16.

[16] USAID Pledges Over \$10M for Emergency Food for Bangladesh, USAID press release, 2007-11-26.

[17] "At least 500 killed in cyclone", CNN (16 November 2007). Retrieved on 2007-11-16. 